Branko Mihailović. PhD. ${ }^{1}$

SCIENTIFIC REVIEW ARTICLE

Drago Cvijanović. Ph.D. ${ }^{2}$

Received: January 20, 2015

Zoran Simonović. PhD. ${ }^{3}$

Accepted: February 16, 2015

Institute of Agricultural Economics, Belgrade

\title{
ROLE OF BUSINESS ETHICS IN MANAGEMENT OF HUMAN RESOURCES
}

\begin{abstract}
The development of modern industry and the system of factory work, together with a large migration of people across oceans and continents, especially during the nineteenth and early twentieth century, has led to major changes in the way people work and do business. The economy shifted from agriculture and family cooperatives to the urban, the industrial organization. The impact of these changes on individuals, professionals, families, communities and the environment, as well as the rise of a new class of wealthy business leaders, but also new areas of poverty, have led to increased reporting of ethical debate. At the same time, if someone has a clear interest in a given company, then to its employees, whose lives and professional careers closely associated with it. Business ethics pays attention to employees (including employees of the management) in several ways. First, most of the ethical problems and crises that occur include operation and participation of employees. Ethical analysis of choice, communication, and behavior of employees occupying a significant part of business ethics. How can managers and owners treat the workers is another ethical issue of interest. Job security, compensation, safety, harassment, prejudice, and even the quality of work experience, are all aspects that are ethically important.
\end{abstract}

Key words: business ethics, human resources management, communications, social responsibility.

JEL classification: M21, M54

\section{УЛОГА ПОСЛОВНЕ ЕТИКЕ У МЕНАЩМЕНТУ ЉУДСКИХ РЕСУРСА ${ }^{4}$}

\begin{abstract}
Апстракт
Развој савремене индустрије и система фабричког рада, заједно са великим миграцијама људи преко океана и континената, посебно током деветнаестог и почетком двадесетог века, довео је до великих промена

\footnotetext{
${ }^{1}$ brankomih@neobee.net

2 dvcmmv@gmail.com

3 zoki@medianis.net

${ }^{4}$ This paper work is result of the project No. 46006 - III „Sustainable agriculture and rural development in function realizing strategic goals of the Republic of Serbia in framework of Danube region", financing by the Ministry of Education and Science of the Republic of Serbia.
} 
у начину на који су људи радили и пословали. Привреда се пребацивала са пољопривреде и породичних задруга на градске, индустријске организаиије. Утицај ових промена на појединце, раднике, породице, заједнииу и на животну средину, као и успон нове класе богатих пословних лидера, али и нових области сиромаштва, довели су до јављања појачане етичке дебате. Истовремено, ако неко има јасан интерес за дату компанију, онда су то нени запослени, чији су животи и професионалне каријере блиско повезани са њом. Пословна етика обраћа пажњу на запослене (укључујући и раднике из менаумента) на неколико начина. Прво, већина етичких проблема и криза које се јављају укључују деловање и учешће запослених. Етичка анализа избора, комуникација и понашања запослених заузима значајни део пословне етике. Како се менацери и власници понашају према радницима друго је етичко питање од интереса. Сигурност на послу, компензације, безбедност, узнемиравање, предрасуде, па чак и квалитет радног искуства, све су то аспекти који су етички битни.

Кључне речи: пословна етика, кадровски менаимент, комуникација, друштвена одговорност.

\section{Introduction}

The creation and transfer of knowledge is a very important aspect of modern society, because new knowledge is helping to rebuild the forms of production and management. This trend is reflected in an increased focus on the economy, expertise and management education. Many companies, especially in sectors with highly educated staff, have introduced or are introducing new management models that support perfection, quality management, creativity in terms of knowledge, organizational and education (Mihailovic, 2011).

The driving force of development and business success resulting from continuous learning and improving managerial skills and abilities. However, changes in the business world, as well as changes of mentality in relation to the way in which jobs are carried out, led to the occurrence of the necessity of analyzing the fairness of the process, not only in terms of the law, but also in terms of morality. As a consequence, conceptualized the new disciplines - business ethics.

\section{Defining Business Ethics}

The emergence of formal study of ethics is coordinated between several authors (e.g., Bauman (Bauman, 1993), Parker (Parker, 1998) et al.). With the modernist Enlightenment project and the idea that moral uncertainty can be resolved by resorting to human rationality and abstract reasoning. The main issue in business ethics is to do the right thing. Different philosophies, religions and individuals gave the answer to "what is right and how do we know?" In different ways, but can be distinguished one general agreement, if not universally, that it is wrong to everything that harms or presents a risk to humans. Old Hippocratic Oath says that the first duty of medical ethics to "do no harm".

So it should be, and in business ethics: ethical business is the one that seeks to avoid damage. What is ethically right and good is what can help people to lead a free, healthy 
and fulfilling life. It is obvious, however, that the damage is an elastic and a relative term but thinking about ethical "good and evil" in this simple, historic, classic terms helps us to focus on a general language and the problems that occur here. (Mihailović, \& Cvijanović, 2013, p.106-116).

For business ethics, it was claimed that the so called. Oxymoron. (Collins, 1994, p. 1-8). The term is an oxymoron involves two seemingly contradictory terms, such as "cheerful pessimist" or "deafening silence". To say that business ethics is an oxymoron therefore says that does not exist or cannot be ethics in business activities, that job is somehow immoral (i.e. That the work is inherently bad) or that, at best, amoral (i.e. outside our usual moral principles). For example, in the latter case, Albert Carr (Albert Carr) is notoriously argued in his article "Does the business playing the moral" to "game" the business was not subject to the same moral standards as the rest of society, but that it should be regarded as analogous to the game poker, in which deception and lies perfectly permissible. (Carr, 1968, p.143-53).

To some extent, it should not surprise us that some people think this way. Various scandals undesirable business activities, such as pollution of rivers by industrial waste, exploitation of workers, giving bribes to government officials and fraud against consumers needlessly stressed the outrageous way that some companies use in their operations. At the same time, the publication of corporate abuse cannot be interpreted in terms of thinking about ethics in business situations is something completely superfluous.

After all, many of the everyday business activities require the maintenance of basic ethical standards, such as honesty, reliability and cooperation. The activity will not be able to survive if corporate directors never tell the truth, if buyers and sellers never trust each other or if the employee refuses, ever, to provide support to each other. Likewise, it would be wrong to conclude that the scandal involving the misuse of corporate indicate the subject of business ethics, in some way, as naive or idealist. Indeed, on the contrary, it can be said that business ethics primarily there to give us some answers related to questions about why certain decisions should be evaluated as ethical or unethical, or correct and incorrect. Accordingly, one of the most important principles of business ethics is reflected in the practical analysis of the ways in which create value in organizations and communities. (Batstone, 2003). In such circumstances, there are certain ethical dilemmas. The ethical dilemma is an example in which there is a difficult question about what is the right thing to do. It often occurs due to a conflict of moral values or principles, either within a single entity or between two or more factors. Focus on the method of examples is called. "Casuistry" which analyzes the ethical dilemmas and problems in order to serve as an aid in making decisions and doing the "right things". (Brown, 2003).

No systematic research, we would not be able to offer anything more than vague opinions or hunches about whether certain business activities are acceptable. Whichever way you look at it, it seems, there is good reason to point out that business ethics as a phenomenon and as an entity that is not an oxymoron. Although it will inevitably be disagreement about what exactly is an "ethical" business activities, the bar is quite possible to offer indisputable definition of the object. So, in short, what is considered to be the topic of business ethics would be:

Business ethics is the study of business situations, activities and decisions referred questions and wrongs. It is worth mentioning that the "correct" and "incorrect" represent what it means morally right and wrong, as opposed to, for example, commercial, strategic or financial "correct" and "incorrect". In addition, the concept of business ethics involves not just commercial jobs, but also government organizations, non-profits, charities and other organizations. At the same time, the study of business ethics has developed more 
institutional character and more attention is devoted to the organization of moral behavior. In the beginning, the attention is focused on determining the factors that stimulate or block the moral behavior. (Bartels, 1967, p. 22-26). In the literature, there is no generally accepted definition of an ethical program. It is often argued that the effective ethical program of continuous process activities that are designed implemented and enforced to prevent and detect failures. (Ferrell, Thorne LeClaire, \& Ferrell, 2000, p. 353-360). Other authors emphasize the common elements of formal ethics programs such as formal codes of ethics, ethics committees, ethical communication systems, ethical supervisors, ethics training programs, disciplinary processes. (Cochran, Trevino, \& Weaver, 1999, p. 41-57).

\section{The Ethical Nature of Human Resource Management}

Personnel management is a business function that deals with the management of relationships between groups of people in their capacity as employees, employers and managers. Inevitably, this process can raise questions about what are the responsibilities and rights of each party in this regard, as well as what constitutes a correct attitude. Personnel management has an ethical basis and deals with the practical consequences of human behavior. However, despite a number of ethical guidelines for human resources management, there is a strong business tradition that insists that business does not need to deal with ethics. As pointed out by Milton Friedman (Milton Friedman), one of the more vocal proponents of this view: "The social responsibility of business is reflected primarily to its shareholders." (Friedman, 1970).

Proponents argue that the market economy is the main purpose of business is reflected in an attempt to ensure the best possible return on total investment. Each "dilution" of this focus will lead to an imbalance precisely balanced market system. Companies, who pretend to be ethical, as well as profitable, probably will not succeed economically, which may adversely affect the entire community. Instead, we should let the invisible hand of the market and manages all will prosper. Like some rules of evolution, the best will always survive, when we will be transferred from the wealth of successful enterprises, which will benefit the entire society.

Regardless of the complaint, according to this way of thinking, a critique of business practice has continued to accumulate and confirming themselves the challenge of challenging the idea that business and morality have no points in common. The interest is coming from different sources: consumer associations, political groups, religious and humanitarian organizations. Entrepreneurs, academics, researchers and managers, all expressed the view that standards of behavior in the business should be evaluated and improved.

On the other hand, the increase in the volume of global business and the elimination of trade barriers worldwide amplifier further interest in the topic of ethical behavior and social responsibility. (Jones, 1991, p. 366-395). How do multinational companies spread globally and entering international markets, the ethical behavior of employees received higher importance because the vast cultural diversity associated with such expansion may threaten the common cultural and ethical values that are observed in homogeneous organizations. (Mahdavi, 2001).

Much of the current focus of business ethics was directed against financial corruption, with particular concern regarding compliance of accounting standards. At the same time, concern has risen to a very broad range of issues, such as:

- Misuse of the world's natural resources and global ecological balance;

- The abuse of human rights; 
- Animal Rights;

- Aggressive treatment of competitors;

- Exploitative and unscrupulous marketing.

Indecent human resource management practices are also erupted in the focus of public attention:

- $\quad$ The use of prisoners as cheap labor;

- The use of child labor;

- Avoidance of assets in pension funds;

- Extended working hours;

- Increased stress at work;

- Murky practices in hiring and firing staff.

It is shown that consumer perception of ethics of the company may affect the sale, such as the attitudes of its investors affect the stock price. Also, set standards of behavior by top management influence on employee motivation and commitment to organizational goals. (Cvijanović, Mihailović,\& Pejanović, 2012).

Personnel on the organizational system, which includes businesses, people make with their professional qualifications and role in the process of doing business, so in theory and practice of human resource management and human resource management called. This term means the activities of human resource management and managers who carry out these activities. (Stavrić, \& Kokeza, 2002, p.365). After a certain time, experience in joint problem solving results in raising the skills and creativity of management at a senior level. This effectively improve management has its theoretical footing. In fact, it extends the basis of strategic management and formed a new approach called - creative management. (Hurst, Rush, \& White, 1996 p.384). Creative management, in line with current trends in the organizational environment, defines the management process, the functions of individual managers in this process and the attributes of those managers who are part of the top management team.

Model creative management is based on the philosophical assumption that the real world, which surrounds the modern organization, dynamic, turbulent and changeable, and that, as such, of the organizations and their management requires performing complex activities. These activities do not require the Serbian managers merely solving the problems caused by uncertainty, but also the identification and exploitation of new business opportunities. Specifically, changes in demand and competition require adjustment of the company's management mindset and marketing strategies alignment with the challenges of the environment. (Cvijanović, Mihailović, Čavlin M., \& Čavlin, G. 2015 p. 1100).

It is evident that the necessary qualitatively new manager features that are geared towards innovation, creativity and change. The implementation of such a complex set of functions includes such membership structure top management team suggests that the differences in terms of cognitive preferences and forms of behavior of team members and their heterogeneous abilities required to perform various activities of the creative process management (as shown in Table 1).

Structuring the creative process level management is performed on the basis of the need for different types of managers. Teamwork manager contributes to the constitution of creative management, ready for the challenges of modern business. Experience in team work is important for holders of creative management, since it is based on the formation of top management teams. For assistance in human resource managers, relying on the science of behavior, they can use a number of methods that facilitate the development and change in individuals, groups or companies to manage the target. These methods include 
professional training groups, transactional analysis, operational analysis, group therapy for certain work, non-verbal communication techniques, organizational development, the motivation for achievement, use of managerial networks and others. (Živanović, 1994, p. 37).

Table 1. Relationships between cognitive preferences and behavior

\begin{tabular}{|c|c|c|c|c|c|}
\hline $\begin{array}{c}\text { Process } \\
\text { Level } \\
\text { KM }\end{array}$ & $\begin{array}{l}\text { Functions KM } \\
\text { process }\end{array}$ & $\begin{array}{l}\text { Cognitive } \\
\text { preference }\end{array}$ & It deals with: & Served: & Examples of conduct \\
\hline I & $\begin{array}{l}\text { imagination } \\
\text { realization }\end{array}$ & intuition & $\begin{array}{l}\text { opportunities } \\
\text { and ideas }\end{array}$ & $\begin{array}{l}\text { metaphors and } \\
\text { symbols }\end{array}$ & $\begin{array}{l}\text { Observe what others } \\
\text { do and advocates for } \\
\text { new ways of handling } \\
\text { things. He proposes } \\
\text { new ideas, ignores the } \\
\text { practical details. For a } \\
\text { description uses metaphors } \\
\text { and symbols. Uses } \\
\text { organizational history } \\
\text { and myths about the } \\
\text { organization. }\end{array}$ \\
\hline II & $\begin{array}{l}\text { motivation, } \\
\text { satisfaction }\end{array}$ & sense & $\begin{array}{l}\text { people and } \\
\text { values }\end{array}$ & $\begin{array}{l}\text { strength of } \\
\text { personality }\end{array}$ & $\begin{array}{l}\text { Inspire your colleagues } \\
\text { and associates. Responds } \\
\text { to requests. Supports } \\
\text { new ideas. Transfers } \\
\text { of information, power, } \\
\text { resources. Keep your } \\
\text { people together. } \\
\text { Rewards awards and } \\
\text { commendations. } \\
\text { Downloads organizational } \\
\text { history and myths about } \\
\text { the organization. }\end{array}$ \\
\hline III & $\begin{array}{l}\text { planning, } \\
\text { evaluation }\end{array}$ & reasoning & $\begin{array}{l}\text { causes and } \\
\text { consequences }\end{array}$ & $\begin{array}{l}\text { regulations and } \\
\text { speech }\end{array}$ & $\begin{array}{l}\text { Aligns the objectives and } \\
\text { resources on the results } \\
\text { (i.e., plans). People } \\
\text { organize, coordinate. } \\
\text { Balancing new and } \\
\text { routine. Rewards when } \\
\text { the results outperform } \\
\text { the plan. }\end{array}$ \\
\hline IV & action & observation & $\begin{array}{l}\text { activities and } \\
\text { events }\end{array}$ & $\begin{array}{l}\text { spontaneity and } \\
\text { action }\end{array}$ & $\begin{array}{l}\text { Aligns skills with } \\
\text { tasks. Attention is paid } \\
\text { to practical details. It } \\
\text { advocates that things } \\
\text { work. The results of his } \\
\text { personal satisfaction. }\end{array}$ \\
\hline
\end{tabular}

Source: Adapted from: Hurst, D.K., Rush, J.C., White, R.E. (1996): 'Top management teams and organizational renewal", in How Organizations Learn, (ed) Ken Starkey, International Thomson Business Press, p. 389.

When analyzing these areas is necessary to focus attention on motivating employees to generate their knowledge. The employee must meet certain standards, technical requirements and standards of production and so on. It is necessary to realize the atmosphere of the company that teaches i.e. of workers to form a skilled and creative personality. It is wrong to workers regarded as mere executors of work orders. An instructive example of Japanese companies, which are characterized by extraordinary productivity, which applies the so-called. Initiative "bottom-up" in the collection of ideas and the decision making, which in future work leads to high motivation of workers. 
One of the main roles of human resource management is the harmonization of the number and structure of human resources with the planned scope and structure of business. The management of human resources is expected to address the employment policy of workers and the main elements of jobs in the organization, i.e. recruitment, training, promotion and relocating workers, wage increases, labor management, etc. First you must perform audits of existing policies and procedures of the workforce, exploring, analyzing and comparing policies with the actual results achieved in a given period, through a systematic audit. To labor policy to be effective, it must meet several criteria: (Kubr, 1976, p. 218).

- policy must be in writing, understandable and presented in its entirety, covering all jobs in the company;

- labor policies must all know and it must be applied throughout the organization;

- $\quad$ policy must be based on logic and arguments, in accordance with public policy and the policies of other companies and organizations;

- $\quad$ policy must be internally consistent with the stated objectives and the general policy of the company;

- $\quad$ specific labor policies (e.g. development and transfer) must be aligned with each other;

- labor policy is the result of discussions at several levels, and a number of consultations across the organization, including consultations with workers' representatives.

Audit staffs provide information on their practices. To achieve this, the information must look vertically through the Department for Employment and horizontally across other departments, which means that an audit conducted throughout the organization. The procedure for conducting audits can be very complex. Basically, it consists of obtaining information on the quantitative and qualitative nature of a number of data and reports supplemented by interviews, questionnaires, surveys, discussions, etc. Information can be obtained through longitudinal research, i.e. research sector by sector, which would be calculated percentages of lost time and the second relates to the comparative basis or can be used transversely research, which thoroughly investigate the effects of these policies on the work of employees. The recommended method for carrying out the audit of the workforce is creating a list of elements of the policy of the organization, to set aside a practice that has been used in the organization. An example is given in Table 2. A complete list of the elements of the policy manpower for the purposes of the audit would include: workforce planning; selection of employees; reassignments and promotions; assessment; training and development; communication; permits, breaks and vacations; assessment of the workplace; benefits; pension and social security; safety and health policy, business relationships, work discipline; motivation and administration. The results of the audit of the labor force, if it is necessary, may indicate the need for defining a change or re-create organizational policies. If the data are inadequate or non-existent, it is necessary to change something in the field of labor. Effective workforce management is only possible when management can use the audit staff as a mechanism for achieving their goals. 
Table 2. The audit staff (the data for the last 12 months)

\begin{tabular}{|l|l|l|}
\hline \multicolumn{1}{|c|}{ These policies } & \multicolumn{1}{|c|}{ Regular practice } & \multicolumn{1}{c|}{ Audit results } \\
\hline $\begin{array}{l}\text { 1. Recruitment } \\
\text { (Promoting, when possible, an } \\
\text { employee of the organization } \\
\text { itself) }\end{array}$ & $\begin{array}{l}\text { Recruitment to the side is a } \\
\text { constant and continuous procedure }\end{array}$ & $\begin{array}{l}\text { 95\% of workers came from } \\
\text { the side. High dropout rate for } \\
\text { workers over 65\% per year }\end{array}$ \\
\hline $\begin{array}{l}\text { 2. Training } \\
\text { (No specific policy) }\end{array}$ & $\begin{array}{l}\text { The organization sends two } \\
\text { higher skilled managers in } \\
\text { courses organized by professional } \\
\text { associations at the request of } \\
\text { interested individuals }\end{array}$ & $\begin{array}{l}\text { Staff stated only limited } \\
\text { opportunities for promotion } \\
\text { and training, feels that } \\
\text { workers have to commute to } \\
\text { another company if they want } \\
\text { to progress }\end{array}$ \\
\hline 3....etc & $\ldots \ldots . .$. & ............ \\
\hline
\end{tabular}

Source: Kubr, M. (1976): Management consulting - A guide to the profession, International Labour Office, Geneva, p. 219.

With this method it is possible to check and assess the performance of managers in the field of labor. This provides us with a comprehensive and high-quality data and reports describing the results obtained a policy of labor. It is recommended to prepare the report forms for individuals with issues relating to their work and that will allow easy evaluation of group information (accidents, overtime, etc.) That is necessary for the revision of the labor force in the future.

\section{Models of Development of Human Resources Management}

Today the concept of social marketing define the needs of the target market and meet them more efficiently and effectively than the competition, so that it maintains or improves the welfare of consumers and society as a whole. In the opinion of one expert in marketing this concept is just "human marketing", on which to base organizations must take a greater social and human responsibility, so as to avoid conflicts with the wishes of users in the short term, as well as giving up their products company in the long run. (Balaure, 2000). Accordingly, it must first be clearly definite quality and quantity of human resources of the company. Determining the need for personnel is part of the planned activities of managers. This is the first task of the human resources function that managers need to perform on the basis of provided answers to the following questions: (Stavrić, \& Kokeza, 2002, p. 367).

1. Who are the jobs necessary to achieve the objectives of the company?

2. What kind of knowledge and skills that should have employee to successfully perform these necessary tasks?

3. How many workers are required to perform certain tasks in the enterprise?

The choice of one person over the other at a certain position is usually based on individual abilities and characteristics. In most examples, there are procedures and techniques for identifying and measuring abilities and skills that are needed for a particular job. The main techniques for selecting workers are testing and interviewing. 
Testing refers to the exploration of knowledge, abilities and skills of the candidates and their behavior on the basis of which predicts future performance. The trend is that more applicable performance tests (measurement of existing skills and knowledge), not aptitude tests (measuring potential). Managers have realized that it is not easy to get a "real" person whose profile fits the job description and that it is therefore necessary to test the relationship with the real needs of workforce planning and employee training programs.

Interviewing is a useful diagnostic tool, but there are a large number of flaws as a predictor of future performance. Managers must be aware of the need for thorough planning and training in this technique, and it is therefore necessary to become familiar with the limitations that apply to this method.

Professional planning and training. For professional planning and training, attention is paid to the growing number of organizations, so managers must be prepared to deal with problems such as:

- $\quad$ Determining the main directions of professional planning and training, which are divided into different categories of employees;

- Analysis of organizational, educational, cultural, social and other obstacles that people face and that sometimes cannot be overcome in their careers;

- Setting up a system in which employees will be encouraged to plan professional development;

- Defining policy of professional development for the organization as well as the criteria (information, training, reassignments, etc.) In order to support and facilitate professional development;

- Designing professional development courses for those who are unlikely to reach the managerial and other senior positions.

Staff development and organization. It is increasingly understood that there are great benefits from development planning workers and managers. There is a growing interest in professional planning and staff training, organizational development and other programs with which to help people to improve their business life and achieve greater fulfillment business.

Assessment of the workplace. During the evaluation of jobs, management must consult with the trade union as well as individual workers. Employee representatives from trade unions are an important factor in decision-making, such as benefits or redundancies. There are a number of techniques for the assessment of the workplace, depending on the job under consideration. Some of their elements are schemes for ranking business, job classification, scoring systems, comparison of factors, and a final assessment.

Motivation. Any organization whose purpose is to achieve certain economic and social goals, trying to motivate their employees toward the goals, which can include social, organizational, group and individual. From management may be required to assist in determining the techniques and strategies to motivate employees. One may refer to:

- $\quad$ improve the overall working environment in the organization, assuming that it greatly affects the motivation of people at all levels in the organization;

- enrichment of the job where the rewards certain behavior, especially financially; because of this there must be a system for feedback, so that the stimulus that is used to connect directly with actual performance. 
The methods are explained not apply independently. They affect different components of the process of motivation and refer to the different degrees of intervention by the management. When assessing the jobs necessary to become familiar with the practice in other industries to constructively solve problems in determining wages.

Evaluation of performance. Experience has shown that the evaluation of performance precisely how levels of performance increase. However, experience shows that the assessment of performance that are used in a large number of organizations, usually not objective criteria but subjective estimations made by supervisors. Assessments must be linked to the actual work performance, whereby supervisors (or other person exercising assessment) must be trained to use techniques of evaluating work performance. Quality assessment depends on the set: organizational, group and individual goals.

\section{Conclusion}

The impetus for the development of business ethics as a field of research and professional practice, especially in the area of human resource management, in recent decades, comes from several sources.

First, the rapid development of technology and its application in the economy have led to changes and increase the traditional list of problems of business ethics. The technology has intensified the old problems, creating new and complicated at the same time and speed up the existing ones.

Secondly, social and cultural events during the sixties of the 20th century led to a more frequent review of traditional ethical rules. The requirements for the recognition and acceptance of the same rights of students, women and ethnic minorities, a new need for taking care of the environment and the increasing ethnic, religious and cultural diversity in the workplace: all these forces and interests helped to re-examine the old ways of doing business and that rethink about what is right and what is wrong. Therefore, just as the ethical problems in the economy increased it was difficult to adopt a common and shared set of ethical values and rules.

Third, the academic and intellectual horizon, there was a growing specialization, that is, on the one hand, fueled range and complexity of various old and new disciplines and research areas, and on the other "explosion" that emerged in the quantity of available data that must be review. The development of specific areas of business ethics (such as medical or bio ethics) became a logical solution, it is possible and necessary. An increasing number of ethical problems, together with the weakening of the general set of values and morals, have created fertile ground for new research and academic specialization.

Fourth, an increasing number of crises and scandals in managerial positions in the economy have led to demands for better government regulation and better supervision of operations, on the one hand, and better education and practices in business ethics on the other side. Scandals in trade, accounting and financial sector, the manipulation of science, dangerous products (cars, tires, drugs), exploitation of children at work, environmental disasters, industrial pollution and depletion of natural resources, but also of growing inequality in wages and bonuses for managers and workers are some of the 
major ethical issues. This litany of ethical scandals and theft among business leaders serving as a strong call for better accession to the idea of business ethics.

Business ethics is essential for long-term success of the business activity, and this is true both on the macro-economic level (immoral behavior can lead to market distortions and to inadequate allocation of resources), and at the microeconomic level (this level is often associated with trust in suppliers, customers, employees and the community), where each organization has certain responsibilities, both socially as well as in the economic sphere.

\section{References}

Balaure, V. (coord.), (2000): Marketing, Bucharest, Uranus Publishing House.

Bartels, J. (1967): “A Model for ethics in marketing”, Journal of Marketing, No 1, pp. 20-26.

Batstone, D. (2003): Saving the Corporate Soul, San Francisco: Jossey-Bass.

Bauman, Z. (1993): Postmodern Ethics, Blackwell, Oxford.

Brown, M. T. (2003): $3^{\text {rd }}$ ed. The Ethical Process: An Approach to Disagreements and Controversial Issues, Upper Saddle River NJ: Prentice-Hall.

Carr, A. (1968): “Is Business Bluffing Ethical?" Harvard Business Review 46, January-February, pp. 143-53.

Cochran, P.L., Trevino, L.K., Weaver, G.R. (1999): “Corporate ethics programs as control systems, influences of executive commitment and environmental factors", Academy of Management Journal, 42, No 1, pp. 41-57.

Collins, J. W. (1994). Is Business Ethics an Oxymoron?. Business Horizons, 37(5), $1-8$.

Cvijanović, D., Mihailović, B., Pejanović, R. (2012): Poslovna etika i komuniciranje, monografija, Institut za ekonomiku poljoprivrede, Beograd.

Cvijanović, D., Mihailović, B., Čavlin, M., \& Čavlin, G. (2015). Impact of Marketing Consulting on Performances of Agrarian Clusters in Serbia. Sustainability, 7(2), 1099-1115. doi:10.3390/su7021099.

Ferrell, O.C., Thorne LeClaire, D., Ferrell, L. (2000): “The Federal Sentencing Guidelines for Organizations; A Framework for Ethical Compliance", Journal of Business Ethics, 17, No 4, pp. 353-363.

Friedman, M. (1970): The social responsibility of business is to increase its profits, New York Times Magazine, 13 September.

Hurst, D.K., Rush, J.C., White, R.E. (1996): “Top management teams and organizational renewal", in How Organizations Learn, (ed) Ken Starkey, International Thomson Business Press, p. 384.

Jones, T. (1991): "Ethical Decision Making by Individuals in Organizations; An issueContingent Model”, Academy of Management Review 16(2), pp. 366-395.

Kubr, M. (1976). Management consulting - A guide to the profession, International Labour Office, Geneva. 
Mahdavi, I. (2001): “American Business Education and Transfer of Culture”, Journal of American Association of Behavioral and Social Sciences, Fall 2001.

Mihailović, B. (2011): Razvoj konsultantskih usluga u Srbiji i njihov uticaj na performanse preduzeća u agrokompleksu, monografija, Institut za ekonomiku poljoprivrede Beograd.

Mihailović, B., Cvijanović, D. (2013): "Ethical challenges in modern business", The $5^{\text {th }}$ International Scientific Conference: Moral effects of economy and economic effects of morality, Hotel Crystal, Belgrade, Published by: Higher Educational Institution for applied studies of Entrepreneurship, Belgrade, 4 June 2013, pp. 106-117.

Parker, M. (Eds.) (1998): Ethics and organizations, London: Sage

Stavrić, B., Kokeza, G., \& Paunović, B. (2002). Upravljanje poslovnim sistemom: ekonomika preduzeća i menadžment. Tehnološko-metalurški fakultet, Beograd.

Živanović, N. (1994). Strukturiranje poželjne konsalting pomoći preduzećima u krizi. Poslovna politika, 6, 30-40. 